\title{
Services Exports and Economic Growth in Sri Lanka: Does the Export-Led Growth Hypothesis Hold for Services Exports?
}

\section{EAC Priyankara}

School of Economics, Huazhong University of Science \& Technology, Wuhan, China

Email: eacpriyankara@yahoo.com

How to cite this paper: Priyankara, E. (2018) Services Exports and Economic Growth in Sri Lanka: Does the Export-Led Growth Hypothesis Hold for Services EXports? Journal of Service Science and Management, 11, 479-495.

https://doi.org/10.4236/jssm.2018.114033

Received: June 28, 2018

Accepted: August 28, 2018

Published: August 31, 2018

Copyright $\odot 2018$ by author and Scientific Research Publishing Inc. This work is licensed under the Creative Commons Attribution International License (CC BY 4.0). http://creativecommons.org/licenses/by/4.0/

\begin{abstract}
Export-led growth hypothesis (ELGH) claims that there is a positive relationship between exports and long-run economic growth. This research study tests the ELGH in the case of services exports analyzing annual time series data from 1984 to 2013 in Sri Lanka. The study employs Granger no-causality procedure developed by Toda and Yamamoto in a vector autoregressive model (VAR) to identify the causality relationship between services exports and GDP. The findings indicate that unidirectional causality is running from services exports to economic growth in Sri Lanka. Therefore, ELGH holds for services exports of Sri Lanka. The results are remained unchanged in the different lag structures and order of integration. Hence, policies to encourage services exports could be of an important driver of Sri Lanka's long-run economic growth.
\end{abstract}

\section{Keywords}

Export-Led Growth, Granger Causality, Services Sector, Exports

\section{Introduction}

Export-led growth hypothesis (ELGH) is one of most debatably discussed topics in exports and economic growth literature. ELGH claims that there is a positive relationship between exports and long-run economic growth. ELGH is not new to the econometric literature; it has roots at least as old as the classical economic thoughts. Several theoretical developments have been made for ELGH. The modern economists are of two views of ELGH supporting classical thought. 1) Export creates competition which leads raising economies of scale and allocation of technical progress in the production [1] [2] [3] [4] [5]. 2) Export is attributed as a foreign exchange earning source, facilitating for imports of capital goods and other 
input which are required in the production [6] [7] [8]. Keynes argues that exports lead expanding the output via foreign trade multiplier in the short-run [9].

However, most of the previous studies that tested ELGH have concentrated on examining the exports-economic growth relationship at aggregate level while few studies deepen the analysis by disaggregating exports into primary, manufactured and services exports. Presently services have become a tradable component in the global trade hence traditional view ${ }^{1}$ on services is no longer valid [10] [11] [12] [13] [14]. The classical economic thought was that services are driven by domestic demand hence the expansion of services beyond the limit causes the detritions of prices [15]. Consideration of causality analysis on services exports is essential due to three reasons. 1) Since last two decades, services value added keeps increasing, up from $58.4 \%$ in 1995 to about $68.29 \%$ of world GDP in 2014. Even in highly indebted countries, the share of value addition of services accounts for 49\% of GDP in 2014 [16]. 2) Trade in services has dramatically increased from about US $\$ 2$ trillion in 2004 to US $\$ 5$ trillion in 2014, of which services exports reached to US\$3 trillion [17]. Presently, trade in commercial services represents about $20 \%$ of the global trade in goods and commercial services [17] [18]. 3) Almost all the economies in the world are in the process of transformation through the stage of economic development; hence, countries will transform towards the services based economies. This will lead to increasing the importance of services in international trade [19], services, previously traded domestically, now increasingly being delivered from abroad [20]. Because of growing importance of services in global trade, the WTO has considered the services in its policy agenda by creating General Agreement on Trade in Services (GATS) in $1995^{2}$ [21]. Similarly, the growing importance of services in world trade has been considered even in the preferential trade agreements (PTA) [22].

As in other economies in the world, Sri Lanka also has undergone significant structural changes over the period. Considering the period from 1950 to 2015, GDP share of agriculture reduced from $46.3 \%$ to $8.1 \%$, the industrial sector increased from $19.6 \%$ to $28.5 \%$. Service sector shows a rapid growth during the referenced period, and the increase is from $36.9 \%$ to $56.3 \%$. In 2015 , the service sector stood with the growth rate of 5.3\% in value added compared to 2014. Services trade in Sri Lanka's economy is becoming important with an increasing trend. Figure 1 shows the pattern of services exports in Sri Lanka. The share of services exports stood at $7 \%$ of GDP in 2013. About $80 \%$ of total services exports in Sri Lanka account for three main services categories such as transport services, travel services and other business services. This study is motivated by above mentioned background \& development and aims to test the ELGH in the case of services exports in Sri Lanka.

'Traditional views of services were that it is none-tradable due to "intangibility" and "no storability" that distinguishes services from goods.

${ }^{2}$ U.S.A. first put forward the proposal to negotiate multilateral rule on policies affecting trade and investment in services in 1980 and it was forwarded to the ministerial meeting of GATT in 1982 (see [21]). After several discussions and considerations, the Uruguay round in the year 1995 the General Agreement on Trade in Services (GATS) was formed. 


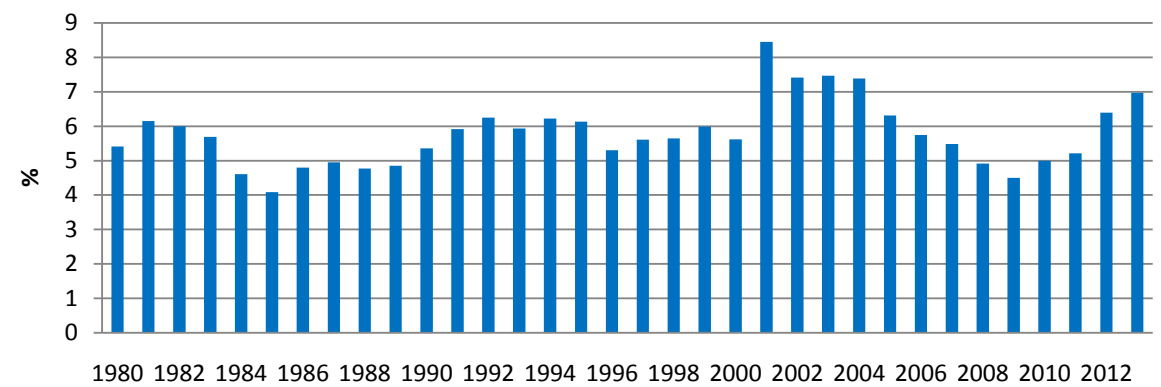

Figure 1. Total services exports as a percentage of GDP (1980-2013). Source: UNCTAD Database.

The contribution of this study is as follows. First, this is one of the first studies, which consider the services exports in testing ELGH in econometric literature. While few researchers have applied time series technique to test the ELGH relevant to services exports, this study is different from theirs and applies Toda-Yamamoto procedure to test causality, hence minimize the risk associated with incorrect identification of integration and cointegration of time series. Second, this study concerns about the robustness of findings. Studies by [23] [24] [25] applying [26] procedure (but they did not consider services exports separately) used different lag structures in their empirical analysis. This study is different from theirs too as it extends the analysis with different order of integration $[I(1)$ and $I(2)]$ along with varying lag structures $(1,2,3,4)$.

The reminder of this paper progresses as follows. Section two provides a literature review of empirical studies on export-led growth relevant to services exports. Section three offers the data used and econometric model specification. Section four presents the empirical results. Section five makes a diagnostic analysis of the estimated models. Section six provides policy implication and section seven is for conclusions.

\section{Literature Review}

The origin of testing ELGH is basically from developed economies, however previous empirical studies supported with this hypothesis even in developing countries which are having a significant growth rate of exports [27] [28]. The developments of studies to test export-economic growth relationships were motivated by the transformation of trade policies from inward-oriented policies of import substitution industries (ISI) towards outward-oriented polices of export promotion (EP) [29]. The extensive empirical studies emphasized the benefits of later against the disadvantage of former. Hong Kong, Singapore, Korea and Taiwan (NICs) adopted with EP and experienced with a higher rate of economic growth, in contrast to the low growth of other inward-oriented economies [23]. The high performance of NICs renewed the interest of the researchers to test whether the high growth is led by exports [23]. Another substantial change that happened in the world economy is that transformation to the service sector at the expense of agriculture and industry. These changes of economic structures 
led the services exports to become as an important component in international trade. One important landmark in international services trade is the introduction of GATS in Uruguay round of GATT in 1995, recognizing the services trade in WTO policy agenda. Recurring rounds of WTO considered the negotiations for achieving a higher degree of services trade liberalization and use of non-tariff barriers [11]. This new step led the attention to reduce trade barriers for services. As the trade in services increased, the interest of researchers directed to test the ELGH with particular focusing for services exports.

The study by [30] for the first time tested the direction of causality between exports and economic growth. Early studies which examined ELGH, more focused on "aggregate" exports. However, some researchers such as, but not limited to [31] [32] [33], made their efforts to identify the economic influence of export at disaggregate level such as primary exports, manufacturing exports and services exports. Their principal argument was that, perhaps although no any causality is detected using total exports, causality might exist at the disaggregated level of exports. Through this study, the focus is to test the ELGH in the case of services exports. It should be noted that the empirical literature of testing ELGH in the case of services exports is not as old as in the case of total exports or goods exports hence, minimal empirical studies. The study by [34], in a regression analysis for 114 countries found services exports significantly and positively influenced on economic growth in developing countries. This study did not focus on causality analysis; instead tested the association between exports and economic growth, however addressed two shortcomings of previous empirical testing of services export-economic growth relationship. First, services exports are themselves a component of output; hence, correlation is insufficient to prove causality because there may be a strong bias in favor of correlation themselves regardless of actual relationship. Second, there is miss-specification of models, excluding other components that are correlated with GDP growth. Gabriele addressed these problems by extending the econometric model with merchandize exports, investment and regional dummies along the services exports. The study by [35] using time series data, examined the relationship between services trade and economic growth in India by employing autoregressive distributed lag model(ARDL), vector error correction model (VECM) and impulse response function. The study found services export-led growth in India. The author has overcome the issue of possible correlation problem by defining the dependent variable as GDP netting out of services exports. Follow up study by [36] applied same time series technique but considered the structural breaks in time series, applying [37] unit root test. The study found no any causality between aggregate exports and non-export GDP while unidirectional causality found from services exports to non-exports GDP, disaggregating the exports into merchandize exports and services exports in India.

However, the results of previous studies may suffer from two shortcomings. First is the test of integration and cointegration properties of time series. Second is the choice of lag structure. The study by [38] pointed out that arbitrary choice 
of lag structure and arbitrary choice of pre-filter may cause false results of causality. The scholar [39] highlighted that the null hypothesis of export does not cause GDP can be spuriously rejected when a unit root or nearly unit root is presented or sub-optimal lag structure is selected. Another study by [40] proposed to conduct the analysis with different lag structures in order to confirm that the findings are not sensitive to lag selection. So far, these issues have not been addressed in the econometric literature of testing services export-led growth hypothesis.

This study accounts for the first issue by applying the Toda and Yamamoto (T-Y) approach [26] of testing Granger no-causality. Toda and Yamamoto [26] proposed a simple causality testing procedure that robust to the integration and cointegration properties of the time series, hence overcome the pre-test bias (see [41] for the explanation of merits of Toda-Yamamoto approach of Granger causality test). In the T-Y approach, the VAR is augmented with $\left(m+d_{\max }\right)^{\text {th }}$ order where $m$ is the lag length and $d_{\max }$ is the maximum order of integration that we suspect might occur in the process [26]. The T-Y approach can be applied when the VAR system has unit roots; the VAR may be stationary, integrated at arbitrary order or cointegrated of an arbitrary order [42]. Further, while applying T-Y approach, this analysis does not limit only to the $\mathrm{d}_{\max }$ suggested by unit root test, instead spread the analysis through different order of integration. This study addresses the second issue by extending the analysis with different lag structure along with optimal lag structure suggested by lag selection criterions. Further, empirical studies that test direction of causality are narrowed to very limited numbers of countries. Hence, weather the export-led growth hypothesis holds in the case of services exports is an empirical question to be further investigated-this study contributes to bridge this gap.

\section{Model Specification and Data}

\subsection{Model Specification}

The model in Equation (1) is constructed to test the causality between services exports and economic growth in long-run. The basic ideas for the econometric model specification are taken from [33] [43] [44]. These authors tested the ELGH in the case of goods exports in a three variable model, which included GDP, goods exports and terms of trade. The study by [45] also adopted with similar type of model to test ELGH for provincial economies of Korea and additionally included national output of Korea. Since the interest of this study is to find the causal relationship between services exports and long-run economic growth, the analysis comprises the services exports and goods exports separately in the model. The causal relationship between exports and economic growth is complex due to various reasons, one such reason is fluctuation of international prices. International price competitiveness is the reflection of fluctuation of real exchange rate and trade policies such as tariffs and non-tariffs barriers [44]. It includes terms of trade in order to control the international price fluctuations. Terms of trade, measured as the ratio of export prices to ratio of import price, influence the size of the exports, imports and trade balance of an economy [43]. 
Two main determinants of exports earning of an economy is the quantity of exports and terms of trade. Hence, exports earning is a result of quantity of exports and terms of trade. Although the quantity of exports remained unchanged, earning from exports is influenced by terms of trade. For instance, terms of trade in Sri Lanka has increased during 1993-2002, which is favorable for Sri Lanka's exports earnings. Sri Lanka as a small open economy, terms of trade is an important variable in explaining the relationship between exports (goods exports and services exports) and economic growth.

$$
G D P_{t}=f\left(S X_{t}, G O O D X_{t}, T O T_{t}\right)
$$

In Equation (1) $G D P_{t}$ is the real gross domestic product in time period " $t$ ". It should be noted that in order to avoid the problem of national account identity the $G D P_{t}$ is defined by netting out of exports following [38] and [32]. $S X_{t}$ is real services exports in time period " $t$ ", GOOD $X_{t}$ is goods exports in in real terms in time period " $\mathrm{t}$ " and $T O T_{t}$ is the terms of trade in time period " $t$ ".

This study employs the Granger non-causality approach proposed by [26] Toda-Yamamoto (T-Y) model can be applied either the series is stationary or integrated of an arbitrary order and cointegrated of arbiter order. The T-Y approach involves the vector autoregressive model (VAR) in level form, hence minimize the risk associated with incorrect identification of integration and cointegration of time series [46] In T-Y approach, lag length $(\mathrm{m})$ is determined by applying usual lag selection procedures and estimated the $\left(m+\mathrm{d}_{\max }\right)^{\text {th }}$ order. The $\mathrm{d}_{\max }$ is the maximum order of integration. There are two steps in estimating the T-Y approach. The first step is determination of $m$ and $d_{\max }$ to estimate the VAR system in the level form [VAR $(m+d m a x)]$. The optimal lag length $(m)$ is determined using AIC, FPE, LR, HQ and SC criterions while ADF and PP tests are performed to determine the maximum order of integration. The second step is MWALD test to identify the causality. The MWALD test is applied to only first $m$ lags to detect the Granger causality. The MWALD test has an asymptotic chi-square distribution with augmented $\operatorname{VAR}\left(m+\mathrm{d}_{\max }\right)$. The study by [47] pointed out that MWALD test for Granger non-causality can be easily computed. The studies by [23] [24] [25] among others applied T-Y approach for Granger non-causality MWALD to examine the relationship between exports and economic growth. Following these authors, the following econometric model is constructed to estimate the Toda-Yamamoto version of granger non-causality test with four variables framework.

$$
\left[\begin{array}{c}
G D P_{t} \\
S X_{t} \\
G O O D X_{t} \\
T O T_{t}
\end{array}\right]=A_{0}+A_{1}\left[\begin{array}{c}
G D P_{t-1} \\
S X_{t-1} \\
G O O D X_{t-1} \\
T O T_{t-1}
\end{array}\right]+A_{2}\left[\begin{array}{c}
G D P_{t-2} \\
S X_{t-2} \\
G O O D X_{t-2} \\
T O T_{t-2}
\end{array}\right]+\left[\begin{array}{c}
\varepsilon_{G D P} \\
\varepsilon_{S X} \\
\varepsilon_{G O O D X} \\
\varepsilon_{T O T}
\end{array}\right]
$$

The Equation (2) is a system equation that generates four simultaneous equations taking GDP, SX, GOODX and TOT as independent variables. Hence $A$ 's represents a coefficient matrix with constant $A_{0}$ [23] [24] [25]. The null hypo- 
thesis of services exports does not Granger cause GDP can be tested as $\mathrm{H}_{0}: \alpha_{1}^{(12)}$ $=\alpha_{2}^{(12)}=0$ against $\mathrm{H}_{1}$ where $\alpha_{1}^{(12)}$ and $\alpha_{2}^{(12)}$ are coefficients of $S X_{t-1}$ and $S X_{t-2}$ respectively in the first equation of the system equation [23] [24] [25]. If the null is rejected significantly, the causality from services exports to GDP is established and says services export-led growth exists. Similarly, the null hypothesis of GDP does not cause services exports also can be tested through $\mathrm{H}_{0}: \alpha_{1}^{(21)}$ $=\alpha_{2}^{(21)}=0$ against $\mathrm{H}_{1}$ where $\alpha_{1}^{(21)}$ and $\alpha_{2}^{(21)}$ are coefficients of $G D P_{t-1}$ and $G D P_{t-2}$ in the second equation of the system [23] [24] [25]. The rejection of null at the statistically significant level is the causality from GDP to services exports, in another word, growth-led services exports hypothesis is established. If $\mathrm{H}_{0}$ is rejected in above both cases, then feedback relationship is established. Further, if $\mathrm{H}_{0}$ is accepted in both case, then no any causal relationship between services exports and GDP [42] [48].

\subsection{Data Sources and Treatment}

This study includes four variables namely GDP, exports of top 3 services, goods exports in real terms [49] and terms of trade index. The data gathered from UNCTAD database and the data covered from 1984 to $2013^{3}$. Except for terms of trade index ${ }^{4}$, all other variables are in million USD. Variables are converted into log form. Following [38] and [32] who used GDP net of exports in their empirical analysis, the dependent variable defines as the GDP net of goods exports and services exports, hence prevents the presence of causality by the variables (exports) themselves due to being a part of the other variable (GDP).

\section{Empirical Results}

\subsection{Descriptive Analysis}

Descriptive analysis of the variables provides some important information about the data such as pattern, trend and variation of the targeted variables. The study by [50] pointed out that the descriptive statistics are essential as a pretest requirement and they provide some useful information regarding the suitability of data. Therefore, Table 1 summarizes the descriptive analysis of the variables in their original form that are included in the analysis. The mean reflects the average value of a variable. Since this analysis is taking annual data for 28 years, one may ask the average expected values for a year. The mean provides the answer. The mean of GDP is $16,027.89$, which means on average Sri Lanka's GDP is 16,027.89 in million USD. Similarly, the annual average contribution of services exports and goods exports to Sri Lankan economy is 811.23 and 3613.08 million USD respectively.

The variation and volatility in the variables during the study period also is an important statistic and it can be measured by slandered deviation (SD). The SD measures the spread of the variable, in other words, how much is the variation ofthe observed values from its average. The GDP shows the highest volatility

${ }^{3}$ Data are available only up to the year 2013 in UNCTAD database.

${ }^{4}$ Values for year 1998 and 1999 were interpolated using EViews. 
followed by goods exports, services exports and TOT.

Table 1. Descriptive analysis.

\begin{tabular}{ccccc}
\hline \multirow{2}{*}{ Statistic } & \multicolumn{4}{c}{ Variable } \\
\cline { 2 - 5 } & GDP & SX & GOODX & TOT \\
\hline Mean & $16,027.89$ & 811.23 & 3613.08 & 100.69 \\
Median & $14,426.37$ & 545.68 & 2986.21 & 100.00 \\
Maximum & $29,656.56$ & 2894.34 & $10,169.20$ & 122.15 \\
Minimum & 9199.12 & 63.28 & 315.85 & 80.43 \\
Std. Dev & 6174.84 & 755.00 & 2782.15 & 10.48 \\
Skewness & 0.766474 & 1.363182 & 0.740707 & 0.065240 \\
Kurtosis & 2.306158 & 4.104089 & 2.790404 & 2.605300 \\
Observation & 28 & 28 & 28 & 28 \\
\hline
\end{tabular}

Source: Authors' calculation.

The distribution of data is also an important feature for statistical analysis. Skewness and "Kurtosis measures whether the targeted variables are following the normal distribution or not? Skewness individually measures deviation from symmetry, in other words it measures the strength of outlier" [50]. All the variables in the analysis are positively skewed, and the highest skewness showing in the services exports. Another important descriptive statistical measure relative to the normal distribution of the variable is peakedness. Kurtosis measures the peakednes of the focused variable. The coefficient values of kurtosis indicate that services export follow peakednes while GDP, goods exports and terms of trade follow flatness.

\subsection{Unit Root Test}

Before proceeding to the analysis, it is important to investigate the unit root properties of the time series in order to determine the order of integration. Among several methods, this study applies augmented Dicky-Fuller (ADF) unit root test and Phillips Perron unit root test to find the order of integration of each time series variable. The unit root tests are performed for 1) constant, 2) constant and trend, and 3) none. ADF test is performed selecting the number of lags using SC information criterion while Phillips Perron test is done employing Newey-West using Bartlett kernel. The results are shown in Table 2 and Table 3.

According to the results, both ADF and PP unit root test results in Table 2 and Table 3 indicate that the all the variables are none stationary at level and become stationary after first difference $I(1)$ at $1 \%$ level. Based on these results, in the [26], maximum order of integration for Sri Lanka is considered as one $\left(\mathrm{d}_{\max }=1\right)$.

Determination of appropriate lag length is very important in the time series analysis. The study selects lag order at 2 for Sri Lanka based on FPE, AIC and HQ criterion. The study performs autocorrelation LM test at selected lag order and the VAR models do not suffer from serial correlation problem ${ }^{5}$. After identifying the lag length and maximum order of integration, the augmented VAR 
system of [26] that is $\mathrm{m}+\mathrm{d}_{\max }$ is determined as $\mathrm{VA}(3)$.

Table 2. ADF unit root test.

\begin{tabular}{|c|c|c|c|c|c|c|c|}
\hline \multirow[t]{3}{*}{ Variable } & \multicolumn{6}{|c|}{$\mathrm{ADF}$ unit root test } & \multirow{3}{*}{$\begin{array}{c}\text { Order of } \\
\text { integration } \\
I()\end{array}$} \\
\hline & \multicolumn{3}{|c|}{ Levels } & \multicolumn{3}{|c|}{$1^{\text {st }}$ Difference } & \\
\hline & $\mathrm{C}$ & $\mathrm{C} \& \mathrm{~T}$ & None & $\mathrm{C}$ & $\mathrm{C} \& \mathrm{~T}$ & None & \\
\hline LGDP1 & 0.423 & -2.010 & 3.024 & $-5.316^{*}$ & $-5.456^{*}$ & $-4.226^{*}$ & $I(1)$ \\
\hline LSX & -1.152 & -2.470 & 1.349 & $-5.548^{\star}$ & $-5.463^{*}$ & $-5.121^{\star}$ & $I(1)$ \\
\hline $\begin{array}{c}\text { LGOOD } \\
\mathrm{X}\end{array}$ & -1.351 & -2.277 & 1.160 & $-5.985^{\star}$ & $-5.950^{*}$ & $-5.622^{\star}$ & $I(1)$ \\
\hline LTOT & -2.423 & $-3.691^{\star *}$ & -0.305 & $-6.017^{*}$ & $-5.864^{*}$ & $-6.157^{\star}$ & $I(1)$ \\
\hline
\end{tabular}

Note: 1) $\mathrm{C}=$ constant, $\mathrm{C} \& \mathrm{~T}=$ constant \& trend. 2) ADF unit root test is done with SC criterion and the automatic lag selection is set as 7.3) $\left(^{*}\right)$ and $\left(^{* *}\right)$ are rejection of null hypothesis at $1 \%$ and $5 \%$ significant levels respectively.

Table 3. Philiips perron unit root test.

\begin{tabular}{cccccccc}
\hline Variable & \multicolumn{3}{c}{ PP unit root test } & & $\begin{array}{c}\text { Order of } \\
\text { integration } \\
I()\end{array}$ \\
\hline & Levels & & & $1^{\text {st }}$ Difference & None \\
\hline CGDP1 & 1.644 & -1.733 & 4.931 & $-5.635^{*}$ & $-10.033^{*}$ & $-4.216^{*}$ & $I(1)$ \\
LSX & -0.836 & -2.502 & 2.307 & $-6.659^{*}$ & $-6.938^{*}$ & $-5.117^{*}$ & $I(1)$ \\
LGOODX & -1.203 & -2.281 & 1.695 & $-6.769^{*}$ & $-7.850^{*}$ & $-5.622^{*}$ & $I(1)$ \\
LTOT & -2.543 & $-3.691^{* *}$ & -0.339 & $-7.797^{*}$ & $-7.663^{*}$ & $-7.791^{*}$ & $I(1)$ \\
\hline
\end{tabular}

Note: 1). C = constant, $\mathrm{C} \& \mathrm{~T}=$ constant $\&$ trend. 2) PP unit root test is done with Newey-West using Bartlett kernel. 3$)\left(^{*}\right)$ and $\left(^{* *}\right)$ are rejection of null hypothesis at $1 \%$ and $5 \%$ significant levels.

\subsection{Granger Causality Analysis}

Table 4 depicts the Granger non-causality test results based on [26] approach. The result rejects the null hypotheses of no causality running from services exports to GDP at $1 \%$ significant level, which implies a unidirectional causality running from services exports to GDP. The MWALD statistics of augmented VAR (3) is 17.43988 with a p-value of 0.0002 . In other words, this study finds strong evidence for export-led growth hypotheses (ELGH) in the case of services exports in Sri Lanka. It also rejects null of no causal relationship running from goods exports to GDP at $1 \%$ significant level and finds unidirectional causality running from goods exports to GDP. This implies that ELGH in the case of goods exports too in Sri Lanka. Further, the study finds unidirectional relationship from terms of trade (TOT) to GDP at $1 \%$ level. The adjusted $\mathrm{R}^{2}$ of LGDP1 equation, which captures the influence of services exports on GDP, is 0.987612 , which implies a significant variation of GDP is explained by dependent variables included in the model. The sum of the lagged coefficient of export variable is 0.506 with positive sign indicating services exports positively influence on the 
economic growth and this result is consistent with [35] [36].

Table 4. Granger causality analysis $\left(m=2, d_{\max }=1\right)$.

\begin{tabular}{ccc}
\hline Null Hypothesis $\left(\mathrm{H}_{\mathrm{o}}\right)$ & MWALD statistic & p-value \\
\hline SX does not cause GDP & 17.43988 & $0.0002^{*}$ \\
GDP does not cause SX & 1.251038 & 0.5350 \\
GOODX does not cause GDP & 13.77710 & $0.0010^{*}$ \\
GDP does not cause GOODX & 1.100700 & 0.5767 \\
TOT does not cause GDP & 10.98372 & $0.0041^{\star}$ \\
GDP does not cause TOT & 2.439738 & 0.2953 \\
\hline
\end{tabular}

*indicates significant at $1 \%$ level.

There are two possible explanations to prove the services export-led growth in Sri Lanka. The first is the time of opening services trade. Sri Lanka, with the auspicious of being a founding member of WTO, liberalized the services trade with GATS commitments and gradually adopted with open policies for services trade [51]. The switch to the outward oriented services trade policies, reducing the degree of protection, implies the strong link between the domestic economy as well as the world market. Hence, the causal relationship between services exports and GDP is possibly detected in the data.

The second explanation is the structure of services exports. During the study period (1984-2013), the average contribution of services exports to total exports in Sri Lanka accounted as $19.77 \%$. Sri Lanka is a net exporter of services. Sri Lanka has long experienced widening the deficit of current account due to an increase in the deficit from goods trade. The surplus of services trade is one of major sources that offset the deficit. Theoretically, foreign exchange earnings via exports can be used to import capital goods and other input required in the production [6] [7] [8]. Hence, services exports via generating a surplus can be a better player in economic growth in Sri Lanka. Moreover, the differences of the composition of services exports also exist. On average, about $7.87 \%$ of total exports of Sri Lanka are attributed by transport services exports, travel services accounted for 5.29\%. More importantly, earning from tourism services in Sri Lanka has become the third largest foreign exchange earner next to the workers' remittances and garments exports. Sri Lanka shares $0.13 \%$ of total tourist arrival and $0.2 \%$ of total tourist earning in the world. The contribution of travel and tourism sector of Sri Lanka to the GDP and employment is above the world and Asia Pacific averages [52]. These explanations reveal that services exports can be a better driver of the growth of Sri Lanka, hence yield empirical evidences for supporting the export-led growth hypothesis.

The results of Table 4 is calculated based on considering lag length suggested by lag selection criterions and order of integration provided by ADF and PP tests. However, this analysis does not limit and rely only on the optimal lag structure proposed by lag selection criterions and order of integration suggested by unit root tests. Considering [53] and [39] arguments and further extending the work by [23] [24] 
[25], this study examines the robustness of results by extending the analysis with different lag structures as well as the different order of integration. Table 5 presents the causal relationship between exports and GDP with different lag structure and considering the maximum order of integration as $I(1)$ while Table 6 considers $I(2)$.

Table 5 and Table 6 depict the results of the causality between services exports and economic growth under the different lag structure and different order of integration. The MWALD test statistics and p-values indicate that principal findings are robust and not sensitive to changes in the selection of lag structure, similar in the sense of [54] Extreme Bound Analysis (EBA) ${ }^{6}$ and also even in the changes in the order of integration. Sum of coefficients ${ }^{7}$ of lagged SX for Sri Lanka was increasing with positive sign through different lags structures and through different order of integration, which further strengthens the finding of the services exports influence on long-run economic growth in Sri Lanka.

\section{Diagnostic Tests}

This study performs different types of diagnostic tests in order to find statistical viability of the analysis. First, it checks the stability of the VAR models testing the inverse root of AR polynomial. If all the inverted roots are inside the unit circle, the VAR model is said to be dynamically stable. In this analysis, inverted roots are strictly inside the unit circle which implies the estimated model is dynamically stable (Figure 2). Next, it performs autocorrelation LM test to find whether the estimated model has serial correlation problem or not. The model does not suffer from serial correlation problem up to ten lags (Table 7). VAR heteroscedasticity test accepts the null of no cross terms in the residuals that indicates the estimated model is homoscedastic (Table 8). Finally, the study performs residual normality test using cholesky of variance (Luktkepohl) and the result accepts the null hypothesis of residuals are multivariate normal (Table 8).

\section{Policy Implication}

This study shows that the rise in the volume of services exports could increase the overall economic growth of Sri Lanka. Therefore, policy makers should develop strategies to promote services exports in international trade. Sri Lankan policy makers can utilize fiscal, financial, and foreign trade policies to encourage and motivate services exporters. The availability of export market information and greater support to acquire advanced technology for services exporting industries could help the services exports to become competitive in the world market and increase the volume exported. Powerful legal and organizational set up for services exports could smooth the exporting process.

A large volume of services exports implies a greater openness for services that could help to re-allocate the resources from less productive and less efficient sectors to more productive and more efficient sectors in the domestic economy.

${ }^{6}$ The result should be summarized from alternative models in order to avoid fragile statistical inferences and yield use full information from the data.

${ }^{7}$ Results are not reported. 
The investment policies supporting such resource allocation could help to enjoy large-scale operation and economies of scale, thereby increase in the services exports. For such benefits, gradual elimination of inter-sectoral barriers to moving resources among sectors could be of importance.

Table 5. Results of granger causality test $\left(d_{\max }=1\right)$.

\begin{tabular}{|c|c|c|}
\hline $\begin{array}{c}\mathrm{H}_{0} \\
\text { Lag Structure (Order of VAR) }\end{array}$ & $\begin{array}{l}\text { SX does not } \\
\text { cause GDP }\end{array}$ & $\begin{array}{l}\text { GDP does not } \\
\text { cause SX }\end{array}$ \\
\hline \multirow{3}{*}{$1(2)$} & MWALD statistic & MWALD statistic \\
\hline & 0.354860 & 0.014842 \\
\hline & {$[0.5514]$} & {$[0.9030]$} \\
\hline \multirow{2}{*}{$2(3)$} & $17.43988^{*}$ & 1.251038 \\
\hline & {$[0.0002]$} & {$[0.5350]$} \\
\hline \multirow{2}{*}{$3(4)$} & $30.92605^{*}$ & 1.644202 \\
\hline & {$[0.0000]$} & {$[0.6494]$} \\
\hline \multirow{2}{*}{$4(5)$} & $118.6050^{*}$ & 0.826071 \\
\hline & {$[0.0000]$} & [0.9349] \\
\hline
\end{tabular}

Note: Figures in parentheses () are $m+d_{\max }$ where $m$ is the lag length and $d_{\max }$ is the maximum order of integration can occur in the VAR system, is considered as $I(1)$. Figures in [ ] are p-values. ${ }^{*}$ indicates significant at $1 \%$ level.

Table 6. Results of granger causality test $\left(\mathrm{d}_{\max }=2\right)$.

\begin{tabular}{ccc}
\hline $\mathrm{H}_{0}:$ & SX does not & GDP does not \\
Lag Structure (Order of VAR) & cause GDP & cause SX \\
\hline \multirow{3}{*}{$1(3)$} & MWALD statistic & 0.063937 \\
& 3.491075 & {$[0.8004]$} \\
$2(4)$ & {$[0.0617]$} & 1.394908 \\
& $21.43952^{\star}$ & {$[0.4979]$} \\
$3(5)$ & {$[0.0000]$} & 2.309976 \\
& $36.75741^{\star}$ & {$[0.5106]$} \\
$4(6)$ & {$[0.0000]^{*}$} & $128.7257^{*}$ \\
& $26.83887^{*}$ & {$[0.0000]$} \\
\hline
\end{tabular}

Note: Figures in parentheses () are $m+d_{\max }$ where $m$ is the lag length and $d_{\max }$ is the maximum order of integration can occur in the VAR system, is considered as $I(2)$. Figures in [ ] are p-values. * indicates significant at $1 \%$ level.

Table 7. Serial correlation LM test.

\begin{tabular}{ccc}
\hline Lags & LM-Stat & Prob. \\
\hline 1 & 11.13692 & 0.8010 \\
2 & 8.670425 & 0.9264 \\
3 & 13.43428 & 0.6408 \\
4 & 10.65762 & 0.8301 \\
5 & 10.26387 & 0.8525 \\
6 & 19.61756 & 0.2379 \\
7 & 13.15106 & 0.6617 \\
8 & 13.05982 & 0.6684 \\
9 & 9.043521 & 0.9116 \\
\hline
\end{tabular}




\begin{tabular}{ccc}
\hline \multicolumn{2}{c}{20.37290} & 0.2039 \\
\hline \multicolumn{3}{c}{ Table 8. Normality and heteroscedasticity test. } \\
\hline Chi-sq (joint) P-value \\
\hline Skewness & 6.162255 & 0.1874 \\
Kurtosis & 7.216665 & 0.1249 \\
Junque-Bera & 13.37892 & 0.0995 \\
Heteroscedasticity Test & 244.1841 & 0.4128 \\
\hline
\end{tabular}

Inverse Roots of AR Characteristic Polynomial

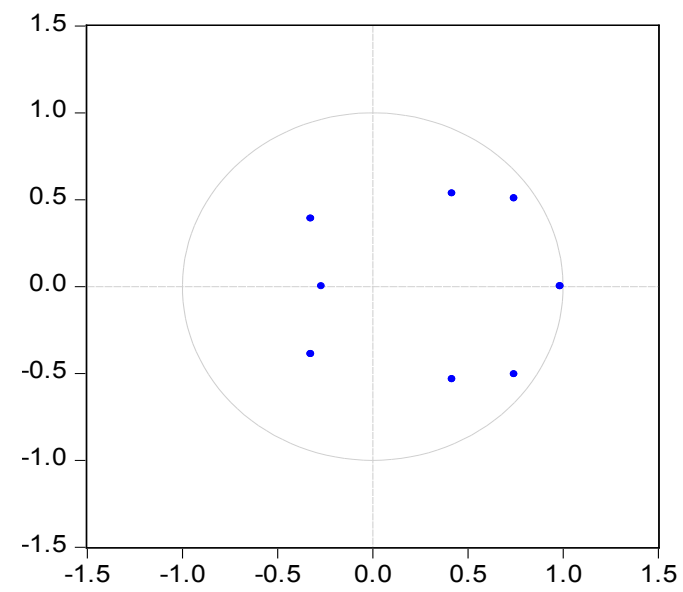

Figure 2. VAR Stability.

Learning by doing from foreign firms could better transfer the technology to the domestic sectors. However, the absorption of such knowledge depends on the level of human capital. Therefore, a mechanism to improve the quality of working population in services sector could help to transfer more technology to the domestic industries. The increase of quality of the workforce will help to improve the innovation capabilities in the service sector, which may contribute to find new space in the global market thereby increasing the services exports.

\section{Conclusion}

This study employs Granger non-causality test developed by Toda and Yamamoto (1995) to investigate the causality between services exports and GDP in Sri Lanka for the period from 1984-2013. The analysis focuses on the robustness of findings with different lag structures and different orders of integration. The study finds results that are more robust. The findings indicate causality running from services exports to economic growth in Sri Lanka. Therefore, services export-led growth hypothesis is accepted for Sri Lanka. The sectoral transformation of Sri Lanka's economy into service based economy is reflected in the international trade too and contributes to the economic growth via services exports, what this study finds here is called as services export-led growth. These findings direct the attention towards an alternative growth model. As a developing 
economy, Sri Lanka has a "new engine of growth" rather than waiting for the old vehicle to come for growth, entering into the services exports, globalization and specialization of services. Hence, Sri Lanka needs policies, promoting and encouraging services exports in enhancing long-run economic growth.

\section{Conflicts of Interest}

The authors declare no conflicts of interest regarding the publication of this paper.

\section{References}

[1] Balassa, B. (1985) Exports, Policy Choices, and Economic Growth in Developing Countries after the 1973 Oil Shock. Journal of Development Economics, 18, 23-35. https://doi.org/10.1016/0304-3878(85)90004-5

[2] Bhagwati, J.N. (1988) Export-Promoting Trade Strategy: Issues and Evidence. World Bank Research Observer, 3, 27-57. https://doi.org/10.1093/wbro/3.1.27

[3] Edwards, S. (1998) Openness, Productivity and Growth: What Do We Really Know? The Economic Journal, 108, 383-398. https://doi.org/10.1111/1468-0297.00293

[4] Krueger, A.O. (1980) Trade Policy as an Input to Development. The American Economic Review, 70, 288-292. https://doi.org/10.3386/w0466

[5] Ram, R. (1987) Exports and Economic Growth in Developing Countries : Evidence from Time-Series and Cross-Section Data. Economic Development and Cultural Change, 36, 51-72. https://doi.org/10.1086/451636

[6] Kugler, P. (1991) Growth, Exports and Cointegration : An Empirical Investigation. Weltwirtschaftliches Archiv, 127, 73-82. https://doi.org/10.1007/BF02707311

[7] McKinnon, R.I. (1964) Foreign Exchange Constraints in Economic Development and Efficient Aid Allocation. The Economic Journal, 74, 388-409. https://doi.org/10.2307/2228486

[8] Riezman, R.G., Whiteman, C.H. and Summers, P.M. (1996) The Engine of Growth or Its Handmaiden? A Time-Series Assessment of Export-Led Growth. Emperical Economics, 21, 77-110. https://doi.org/10.1007/BF01205495

[9] Moosa, I.A. (1999) Is the Export-Led Growth Hypothesis Valid for Australia? Applied Economics, 31, 903-906. https://doi.org/10.1080/000368499323869

[10] Ball, D.A., Lindsay, V.J. and Rose, E.L. (2008) Rethinking the Paradigm of Service Internationalization: Less Resource-Intensive Market Entry Modes for Information-Intensive Soft Services. Management International Review, 48, 413-431. https://doi.org/10.1007/s11575-008-0024-x

[11] Banga, R. (2005) Trade in Services : A Review. Global Economy Journal, 5, 1-22. https://doi.org/10.2202/1524-5861.1068

[12] Conti, G., Turco, A.Lo. and Maggioni, D. (2014) Spillovers through Backward Linkages and the Export Performance of Business Services. Evidence from a Sample of Italian Firms. International Business Review, 23, 552-565. https://doi.org/10.1016/j.ibusrev.2013.09.003

[13] Lennon, C. (2008) Trade in Services and Trade in Goods : Differences and Complementarities. PSE Working Paper N2008-52.

[14] Roberts, J. (1999) The Internationalization of Business Service Firms: A Stages Approach. The Service Industries Journal, 19, 68-88.

https://doi.org/10.1080/02642069900000045 
[15] Ghani, E. (2010) The Service Revolution in South Asia. Oxford University Press, New Delhi.

[16] WB (The World Bank) (2016) World Development Indicators.

[17] UNCTAD (United Nations Conference on Trade and Development) (2015) Key Statistics and Trends in International Trade.

[18] WTO (World Trade Organization) (2014) World Trade Report: Trade and Development: Recent Trends and the Role of the WTO.

[19] White, D.S., Ariguzo, G.C. and Curran, C.M. (2013) Using Time Series Analysis to Predict U.S. Service Exports. Services Marketing Quarterly, 34, 175-190. https://doi.org/10.1080/15332969.2013.770706

[20] Lautier, M. (2008) Export of Health Services from Developing Countries: The Case of Tunisia. Social Science \& Medicine, 67, 101-110. https://doi.org/10.1016/j.socscimed.2008.01.057

[21] Francois, J. and Hoekman, B. (2010) Services Trade and Policy. Journal of Economic Literature, 48, 642-692. https://doi.org/10.1257/jel.48.3.642

[22] Shingal, A. (2009) How Much Do Agreements Matter for Services Trade? https://Mpra.Ub.Uni-Muenchen.de/32815/1/MPRA_paper_32815.Pdf

[23] Shan, J. and Sun, F. (1998) On the Export-Led Growth Hypothesis for the Little Dragons: An Empirical Reinvestigation. Atlantic Economic Journal, 26, 353-371. https://doi.org/10.1007/BF02299449

[24] Shan, J. and Sun, F. (1999) Export-Led Growth and the US Economy: Some Further Testing. Applied Economics Letters, 6, 169-172. https://doi.org/10.1080/135048599353564

[25] Shan, J. and Sun, F. (1998) On the Export-Led Growth Hypothesis: The Econometric Evidence from China. Applied Economics, 30, 1055-1065. https://doi.org/10.1080/000368498325228

[26] Toda, H.Y. and Yamamoto, T. (1995) Statistical Inference in Vector Autoregressions with Possibly Integrated Processes. Journal of Econometrics, 66, 225-250. https://doi.org/10.1016/0304-4076(94)01616-8

[27] Balassa, B. (1978) Exports and Economic Growth: Further Evidence. Journal of Development Economics, 5, 181-189. https://doi.org/10.1016/0304-3878(78)90006-8

[28] Feder, G. (1982) On Exports and Economic Growth. Journal of Development Economics, 12, 59-73. https://doi.org/10.1016/0304-3878(83)90031-7

[29] Tyler, W.G. (1981) Growth and Export Expansion in Developing Countries: Some Emperical Evidence. Journal of Development Economics, 9, 121-130. https://doi.org/10.1016/0304-3878(81)90007-9

[30] Jung, W.S. and Marshall, P.J. (1985) Exports, Growth and Causality in Developing Countries. Journal of Development Economics, 18, 1-12. https://doi.org/10.1016/0304-3878(85)90002-1

[31] Abu-qarn, A.S. and Abu-Bader, S. (2004) The Validity of the ELG Hypothesis in the MENA Region: Cointegration and Error Correction Model Analysis. Applied Economics, 36, 1685-1695. https://doi.org/10.1080/0003684042000266865

[32] Herzer, D., Nowak-Lehmann D, F. and Siliverstovs, B. (2006) Export-Led Growth in Chile: Assessing the Role of Export Composition in Productivity Growth. The Developing Economies, 44, 306-328. https://doi.org/10.1111/j.1746-1049.2006.00019.x

[33] Rangasamy, L. (2009) Exports and Economic Growth: The Case of South Africa. Journal of International Development, 21, 603-617. https://doi.org/10.1002/jid.1501 
[34] Gabriele, A. (2006) Exports of Services and Economic Growth in Developing Countries. Journal of Economic Integration, 21, 294-317. https://doi.org/10.11130/jei.2006.21.2.294

[35] Dash, R.K. and Parida, P.C. (2012) Services Trade and Economic Growth in India: An Analysis in the Post-Reform Period. International Journal of Economics and Business Research, 4, 326-345. https://doi.org/10.1504/IJEBR.2012.046824

[36] Debnath, A., Laskar, A.B., Bhattacharjee, N. and Mazmuder, N. (2014) Is India's GDP Really Led by Export? A Further Examination. Journal of Transnational Management, 19, 247-260. https://doi.org/10.1080/15475778.2014.960784

[37] Perron, P. (1997) Further Evidence on Breaking Trend Functions in Macroeconomic Variables. Journal of Econometrics, 80, 355-385. https://doi.org/10.1016/S0304-4076(97)00049-3

[38] Ghatak, S., Milner, C. and Utkulu, U. (1997) Exports, Export Composition and Growth: Cointegration and Causality Evidence for Malaysia. Applied Economics, 29, 213-223. https://doi.org/10.1080/000368497327272

[39] Xu, Z. (1998) Export and Income Growth in Japan and Taiwan. Review of International Economics, 6, 220-233. https://doi.org/10.1111/1467-9396.00099

[40] Pindyck, R.S. and Rubinfeld, D.L. (1991) Econometric Models and Economic Forecasts. McGraw-Hill, New York.

[41] Shirazi, N.S. and Manap, T.A.A. (2005) Export-Led Growth Hypothesis: Further Econometric Evidence from South Asia. The Developing Economies, 43, 472-488. https://doi.org/10.1111/j.1746-1049.2005.tb00955.x

[42] Esso, L.J. (2010) Long-Run Relationship and Causality between Foreign Direct Investment and Growth: Evidence from Ten African Countries. International Journal of Economics and Finance, 2, 168-177. https://doi.org/10.5539/ijef.v2n2p168

[43] Dhawan, U. and Biswal, B. (1999) Re-Examining Export-Led Growth Hypothesis: A Multi Variate Cointegration Analysis for India. Applied Economics, 31, 525-530. https://doi.org/10.1080/000368499324246

[44] Henriques, I. and Sadorsky, P. (1996) Export-Led Growth or Growth-Driven Exports? The Canadian Case. Canadian Journal of Economics, 29, 540-555. https://doi.org/10.2307/136249

[45] Jin, J.C. (2002) Exports and Growth: Is the Export-Led Growth Hypothesis Valid for Provincial Economies? Applied Economics, 34, 63-76. https://doi.org/10.1080/00036840010025632

[46] Amiri, A. and Ventelou, B. (2012) Granger Causality between Total Expenditure on Health and GDP in OECD: Evidence from the Toda-Yamamoto Approach. Economics Letters, 116, 541-544. https://doi.org/10.1016/j.econlet.2012.04.040

[47] Rarnbaldi, A.N. and Dora, H.E. (1996) Testing for Granger Non-Causality in Cointegrated Systems Made Easy. No. 88.

[48] Bildirici, M. and Ersin, Ö. (2015) An Investigation of the Relationship between the Biomass Energy Consumption, Economic Growth and Oil Prices. Procedia-Social and Behavioral Sciences, 210, 203-212. https://doi.org/10.1016/j.sbspro.2015.11.360

[49] Rahman, M. and Mustafa, M. (1997) Dynamics of Real Exports and Real Economic Growths in 13 Selected Asian Countries. Journal of Economic Development, 22, 81-95.

[50] Mahmood, K. and Munir, S. (2017) Agricultural Exports and Economic Growth in Pakistan: An Econometric Reassessment. Quality and Quantity, 52, 1561-1574. https://doi.org/10.1007/s11135-017-0534-3 
[51] WTO (World Trade Organization) (2014) Trade Policy Review of Sri Lanka.

[52] Central Bank of Sri Lanka (2015) Annual Report.

[53] Ghartey, E.E. (1993) Causal Relationship between Exports and Economic Growth: Some Empirical Evidence in Taiwan, Japan and the US. Applied Economics, 25, 1145-1152. https://doi.org/10.1080/00036849300000175

[54] Leamer, E. and Leonard, H. (1983) Reporting the Fragility of Regression Estimates. The Review of Economics and Statistics, 65, 306-317.

https://doi.org/10.2307/1924497 